\title{
Potential of Trichoderma spp. on Growth Promotion and Mitigating Cadmium Uptake in Rice Plant under the Metal Stress Ecosystem
}

\author{
N. Nongmaithem ${ }^{1}$, A. Roy $^{2 *}$ and P.M. Bhattacharya ${ }^{2}$ \\ ${ }^{1}$ ICAR Research Complex for NEH Region, Manipur Centre, Lamphelphat-795004, India \\ ${ }^{2}$ Department of Plant Pathology, Uttar Banga Krishi Viswavidyalaya, Pundibari, \\ Cooch Behar 736165, West Bengal, India \\ *Corresponding author
}

\section{A B S T R A C T}

This study was designed to investigate the efficacy of the biocontrol isolates on growth promotion and ability in lowering the metal uptake by rice plant (variety MTU 7029) with

\section{Keywords}

Rice,

Trichoderma,

Growth promotion, Cadmium stress.

Article Info

Accepted:

17 May 2017

Available Online:

10 June 2017 two Trichoderma isolates namely MT-4 and UBT-18 both having tolerance towards cadmium. Substantial variations had been found in different treatments. Significant increase in chlorophyll was observed in Trichoderma treated plants at $25 \mathrm{ppm}$ stress. Total protein estimation in Trichoderma treated and non-treated rice plants under cadmium stress showed that protein content decreased significantly with increasing metal concentration in Trichoderma non treated plants. Trichoderma isolates helped in construction of significantly more protein with cadmium gradient. Peroxidase activity showed increasing trend up to $25 \mathrm{ppm}$ followed by gradual decline. The enzyme activity in Trichoderma treated plants was always lower compared to non-treated plants. In Trichoderma non-amended treatment, cadmium concentration in plant increased with increased in level of cadmium contamination which was equivalent with decreasing biomass of the plants. The cadmium uptake by rice plants increased with increasing cadmium contamination ranging from 6.66 to $6.99 \mu \mathrm{g}$ g-1 plant biomass. The plant treated with Trichoderma on the other hand gained higher biomass which might be correlated with lower cadmium concentration in plants. It was observed that MT-4 treated plants contained lower cadmium coupled with higher biomass as compared to UBT-18.

\section{Introduction}

Metal containing pollutants are increasingly being released into the soil from industrial waste water as well as from wastes derived from chemical fertilizers and pesticides used in agriculture (Lopez and Vazquez, 2003; Ting and Choong, 2009). Major problem with metals is their tendency to persist indefinitely in the food chain (Gupta et al., 2000; Aleem et al., 2003). Their accumulation reduces soil fertility, soil microbial activity, plant growth and quality of agricultural products. Cadmium is one of the most ubiquitous and potentially hazardous contaminants in the biosphere. Phosphatic fertilizers are widely regarded as being the most ubiquitous source of cadmium contamination of agricultural soils (Alloway, 1995). Cadmium is readily absorbed by plant roots within a few hours of its supply to roots media and from there is easily transported to other parts of the plants (Ghoshroy and 
Nadakavukaren, 1990; Rauser and Meuwly, 1995). In most of the cadmium stressed ecosystem, the heavy metal easily penetrates the roots through cortical tissues and reaches the xylem through apoplastic and /or symplastic pathway (Salt et al., 1995). Normally cadmium ions are retained in the roots and only small amount are transported to the shoot as also indicated by Cataldo et al., (1983). The inhibitory effect of cadmium ions on root elongation is mediated through altered cell growth. Cadmium in cells gets associated with cell walls and middle lamella and increases the cross linking between the cell wall components resulting in inhibition of the cell growth (Poscherieder et al., 1989). The reduction of biomass by cadmium toxicity was attributed to the direct consequence of inhibition of chlorophyll synthesis and photosynthesis (Padmaja et al., 1990). Moreover, cadmium also alters the water relations in plants, causing physiological drought (Barcelo and Poscherieder, 1990) and metabolic dysfunctions such as reactive oxygen species (Asada, 1999). These and some other altered processes like pollen fertility, proline content, nitrate reductase activity lead to the decrease in the length and fresh and dry mass of the plants subject to cadmium stress (Parveen et al., 2011).

Trichoderma species are imperfect filamentous fungi, with teleomorphs belonging to the hypocreales order of the ascomycete division. Trichoderma spp. have great role in ecology as they take part in decomposition of plant residues as well as biodegradation of man- made chemicals and bioaccumulation of high amount of different metals from waste water and soil (Ezzi and Lynch, 2005; Anand et al., 2006). Evidence suggested that Trichoderma spp. exhibited considerable tolerance against metals and accumulate high amount of the metals from polluted habitants (Lopez and Vazquez, 2003;
Anand et al., 2006). Therefore, metal tolerant Trichoderma species may become dominant organisms in some polluted and play an important role in environment friendly metalremoval technology (Ting and Choong, 2009). Also metal ions in soil may influence growth, sporulation and enzymatic activities of Trichoderma spp. (Jaworska and Dluzniewska, 2007) which can cause changes in the quantities of extra cellular enzymes produced and metabolites (Kredics et al., 2001a, b) as well as overall biocontrol activities against plant pathogenic fungi and plant growth stimulating factors. However, the micro habitat behaviour of Trichoderma spp. upon exposure to each metal-containing compound may differ depending on type of metal and ability to detoxify it by Trichoderma isolates. In this background, the present study was undertaken to investigate the effect of Trichoderma on physical and biochemical attributes of rice plant under cadmium stress ecosystem and also to correlate the ability of the biocontrol agent for accumulation of the toxicant aimed towards reducing the chance of cadmium uptake by the plant.

\section{Materials and Methods}

Two cadmium tolerant Trichoderma isolates namely MT-4 and UBT-18 were taken to study their effect on growth promoting ability with concomitant decrease of cadmium uptake in rice plants under cadmium stress ecosystem. The rice (var. MTU 7029) seedlings were raised in perforated aluminium tray containing sterilized soil-farm yard manure mix (3:1). The recommended fertilizer dose (N: P: K 10:10:10) was applied before sowing. Irrigation was provided frequently. The seedling was ready for transplanting at 25 days of sowing. Soil and FYM mix containing different concentrations of cadmium $(0,5,10,25$ and 50ppm) was prepared separately in earthen pots with the 
metal standard solution made in sterilized double distilled water. Soil and FYM mix without any metal amendment was served as control. Fertilizer dose was applied in the form of balanced fertilizer @ 2g/kg of potting mix. The mixes were kept in pots for one month to stabilize the toxicity with intermittent application of the solution of respective concentration. Recommended fertilizer dose was applied before sowing and Trichoderma isolates were applied at the population level of $107 \mathrm{cfu} / \mathrm{g}$ of soil. The Trichoderma non-amended metal containing soil served as control. The rice seedlings were transplanted and frequent irrigation was provided with tap water. Chlorophyll, protein and poly phenol oxidase content in leaf was estimated at 30 days after transplanting, whereas, cadmium concentration in plant was measured at 75 days of crop age.

\section{Chlorophyll estimation}

Portable Chlorophyll Meter SPAD-502 (Minolta Corporation, NJ, and USA) was used for spectral measurement of total chlorophyll in rice at six randomly chosen leaves per individual rice plant, taking two leaves from the top, middle and bottom, respectively, and the average value for each sample site was calculated.

\section{Protein estimation}

Fresh leaves weighing $0.2 \mathrm{~g}$ was crushed in a previously chilled mortar with pestle in $0.8 \mathrm{ml}$ of sodium phosphate buffer $(\mathrm{pH} \mathrm{7.1)}$. The grind tissue was centrifuged at $4^{\circ} \mathrm{C}$ for 20 minutes at 10,000 rpm and the supernatant was used as crude protein. Total protein was estimated following Lowry's method (1951).

\section{Peroxidase estimation}

The peroxidase (PO) activity was determined by the method described by Sadasivam and Manickam (1996). The enzyme extract was prepared by taking $0.2 \mathrm{~g}$ of fresh healthy tissue in $0.8 \mathrm{ml}$ of $0.1 \mathrm{M}$ phosphate buffer $(\mathrm{pH}$ 7.1) by grinding with a pre cooled mortar and pestle at 0 degree $c$ and the homogenate was centrifuged at $20,000 \mathrm{rpm}$ at $4^{\circ} \mathrm{C}$ for 20 minutes. The supernatant was used as enzyme source.

In a cuvette $3 \mathrm{ml}$ buffer $(0.05 \mathrm{M})$ Pyrogallol solution, $0.1 \mathrm{ml}$ enzyme extract and $0.5 \mathrm{ml}$ hydrogen peroxide were taken by using micropipette and were mixed well. Therefore the cuvette was placed in the Spectrophotometer and the absorbance was measured at $490 \mathrm{~nm}$ in a spectrophotometer against a reagent blank without enzyme extract at an interval of 30 seconds. Enzyme activity was expressed as change in absorbance $\min ^{-1} \mathrm{~g}^{-1}$ tissue.

\section{Analysis of cadmium in rice plant}

To determine the cadmium concentration in rice at the time of flowering, the entire plants along with roots in each pot were carefully removed, washed free of adhering soil particles with water and air-dried. For dry biomass measurement the roots and shoots dried in a forced-air oven for 2 days at $50^{\circ} \mathrm{C}$, followed by 3 days at $80^{\circ} \mathrm{C}$ and overnight at $105^{\circ} \mathrm{C}$. Biomass of the roots and shoots was measured by using Sartorius LA8200S digital weight balance on the basis of wet weight and dry weight. Dried material was ground to homogenous powder using mill grinder. The sample was then digested by using triacid digestion method using a mixture of $\mathrm{HNO}_{3}: \mathrm{H}_{2} \mathrm{SO}_{4}: \mathrm{HCLO}_{4}$ in the ratio of $9: 4: 1$ following the method of Tandon (2005). $0.5 \mathrm{~g}$ ground plant material is placed in $100 \mathrm{ml}$ clean beaker and to that $10 \mathrm{ml}$ of triacid mixture was added and the content of the flask is mixed by swirling and keep it for overnight. The flask was placed on low heat hot plate at $60^{\circ} \mathrm{C}$ in a digestion chamber. Then, the flask is heated at higher temperature until the production if red $\mathrm{NO}_{2}$ fumes ceases. 
The content was further evaporated until the volume was reduced to about 2 to $3 \mathrm{ml}$ but not to dryness. The completion of digestion is confirmed when the liquid become colourless.

After cooling the flask, it was transferred quantitatively to $50 \mathrm{ml}$ capacity volumetric flask, diluted to $50 \mathrm{ml}$ with distilled water and kept overnight. Next day it was filtered through Whatman no. 44 filter paper. The filtrate was stored properly and was analyzed for the estimation of cadmium using AA Flame Spectrophotometer (Model: AAnalyst 200, S/N 200S6040301 Autosampler Model). Each sample was analyzed two or three times at a wave length of $229 \mathrm{~nm}$. Concentrations were expressed in terms of $\mathrm{mg} / \mathrm{kg}$.

\section{Quantification of cadmium accumulation in Trichoderma}

This study was carried out with one test isolate of Trichoderma sp. (UBT-18) to establish a correlation between the biomass production and cadmium accumulation. The test isolate was grown in metal amended PDA medium of different concentrations $(0,25,50$, 100 and $150 \mathrm{ppm}$ ) at $27 \pm 1^{\circ} \mathrm{C}$ for 7 days. The biomass was harvested through cheese cloth and oven dried at $40^{\circ} \mathrm{C}$. After complete drying the biomass was weighted. The cadmium accumulation by the Trichoderma isolate was quantified by taking $0.5 \mathrm{~g}$ of dried biomass and following the triacid digestion method as described above.

\section{Results and Discussion}

The results directed towards the hypothetical inference of having significant role of Trichoderma in annulling the adverse effect of cadmium in rice plant. Attempt had been made to evaluate the growth promotion and to quantify the metal uptake in rice plants grown under cadmium stress at panicle emergence stage with two Trichoderma isolates namely MT-4 and UBT-18 both of having tolerance towards cadmium. Substantial variations had been found in different treatments. The variation in chlorophyll content in MT-4 and UBT-18 treated plants were measured under elevated cadmium stress and the results obtained have been presented in figure 1. It was observed that cadmium stress had significant effect on reduction of chlorophyll content in leaf. The use of tolerant Trichoderma spp. helped in enhancing the chlorophyll irrespective of a particular cadmium concentration. The isolates varied in response to increase in the chlorophyll content under cadmium stressed condition. UBT-18 was found to induce significantly more chlorophyll at 50ppm cadmium stress. Significant decrease in protein content was observed with increasing concentration of cadmium irrespective of tolerant Trichoderma spp (Fig. 2). However, application of Trichoderma isolates aided in increasing amount of protein construction irrespective upon exposure to different level of metal stress. Among the isolates, UBT-18 was more potent in enhancing the protein level in plants at $50 \mathrm{ppm}$ cadmium stress $\left(1.46 \mathrm{mg} \mathrm{g}^{-1}\right.$ fresh wt) as compared to MT-4 (1.32 mg g ${ }^{-1}$ fresh wt).

Peroxidase activity in rice plants under the interaction of cadmium and Trichoderma isolates revealed that the enzyme activity in Trichoderma non-treated plants increased with increasing cadmium level up to $25 \mathrm{ppm}$ followed by modest decrease at 50ppm. In Trichoderma treated plants peroxidase activity was always comparatively low irrespective of isolates concerned. However, at initial level of cadmium contamination, peroxidase activity showed increasing trend in Trichoderma treated plants. With further increase in cadmium level significantly low peroxidase activity was recorded in Trichoderma treated plants except UBT-18 where gradual increase in peroxidase activity was found (Fig. 3). The result presented in table 1 revealed that in Trichoderma non- 
amended treatment, cadmium concentration in plant increased with increase in level of cadmium which was equivalent with decreasing biomass of the plants. Simultaneously, the cadmium uptake by rice plants increased with increasing cadmium contamination ranging from 6.66 to $6.99 \mu \mathrm{g}$ plant $^{-1}$. The plants treated with Trichoderma on the other hand gained higher biomass in comparison to the plant without Trichoderma which might be correlated with lower cadmium concentration in plants treated with Trichoderma. Comparing the ability of two isolates, it was observed that plants treated with MT-4 contained lower cadmium coupled with higher biomass than plants treated with UBT-18. The results depicted in figure 4 and 5 conferred that negative relation exists among plant cadmium concentration and its biomass.

In this present investigation, cadmium toxicity in rice plants were measured under dual interaction of Trichoderma and heavy metals and compared with Trichoderma non treated plants grown under only heavy metal stress. Cadmium damages the photosynthetic apparatus (Sidlecka and Baszynsky, 1993), lowers chlorophyll content (Larsson et al., 1998), and inhibits the stomatal opening (Barcelo and Poschenrieder, 1990). With increase in metal contamination in Trichoderma non-treated treatment there was a significant reduction in chlorophyll content. Heavy metal stress in soils results in subtle changes of leaf chlorophyll concentration in rice, which are related to crop growth and crop yield (Liu et al., 2010). High concentrations of heavy metals can degrade the activities of photosynthetic enzymes and block the photosynthetic electron transport chain, resulting in reduction of chlorophyll content (Thapar et al., 2008). Decrease in chlorophyll content may be due to reduce synthesis of chlorophyll as a result of inhibition of enzyme activity such as $\delta$ aminolevulinic acid dehydratase (Padmaja et al., 1990) and protochlorophyllide reductase (Van Assche and Clijsters, 1990), replacement of $\mathrm{Mg}$ with heavy metals in chlorophyll structure, decrease in source of essential metals that involved in chlorophyll synthesis such as $\mathrm{Fe}^{2+}$ and $\mathrm{Zn}^{2+}$ (Kupper et al., 1998), destruction of chloroplast membrane by lipid peoxidation due to increase in peroxidase activity and lack of antioxidants such caretenoids (Prasad and Strzalka, 1999), decrease in density, size and synthesis of chlorophyll and inhibition in the activity of some enzymes of Calvin cycle (Benavides et al., 2005).

One possible mechanism by which excess heavy metals may damage plant tissues is the stimulation of free radical production, by imposing oxidative stress (Foyer et al., 1997). Significant increase in chlorophyll was observed in Trichoderma treated plants in comparison to non-treated plants. MT-4 and UBT-18 were found to enhance chlorophyll production at $25 \mathrm{ppm}$ nickel and cadmium stress, respectively. Role of Trichoderma in inducing chlorophyll content in plant has been reported by several workers. Trichoderma treatments significantly increased the growth of maize plants as compared to the control. Trichoderma-treated plants were able to enhance nutrient uptake, resulting in increasing root and shoot growth, and improving plant vigour to grow more rapidly with enhanced plant greenness, which resulted in higher photosynthetic rates (Harman, 2006). Such increased carbohydrate production under stress condition facilitated to high biomass production of the plant. Plant genes respond to pathogens and elicitors. For this reason, plant defense mechanisms do not necessarily require stimulation by the living organism. The addition of Trichoderma metabolites may act as elicitors of plant resistance, or the expression in transgenic plants of genes whose products act as elicitors. 
Table.1 Effect of Trichoderma isolates on cadmium uptake in rice plants under cadmium stressed condition

\begin{tabular}{|c|c|c|c|c|c|c|c|}
\hline Isolate & $\begin{array}{c}\text { Cadmium } \\
\text { concentratio } \\
\text { n (ppm) }\end{array}$ & $\begin{array}{c}\text { Dry wt. of } \\
\text { plants (g) } \\
\text { Trichoderma } \\
(-)\end{array}$ & $\begin{array}{c}\text { Dry wt. of } \\
\text { plants (g) } \\
\text { Trichoderma } \\
(+)\end{array}$ & $\begin{array}{c}\text { Cadmium } \\
\text { concentration in } \\
\text { plants }(\mu \mathrm{g} / \mathrm{g}) \\
\text { Trichoderma }(-)\end{array}$ & $\begin{array}{c}\text { Cadmium } \\
\text { concentration } \\
\text { in plants }(\mu \mathrm{g} / \mathrm{g}) \\
\text { Trichoderma } \\
(+)\end{array}$ & $\begin{array}{c}\text { Cadmium uptake } \\
\text { ( } \mu \text { g/plant) in } \\
\text { Trichoderma }(-)\end{array}$ & $\begin{array}{c}\text { Cadmium } \\
\text { uptake } \\
\text { ( } \mu \text { g/plant) in } \\
\text { Trichoderma } \\
\quad(+)\end{array}$ \\
\hline \multirow{4}{*}{ UBT-18 } & $5 \mathrm{ppm}$ & 5.82 & 6.31 & 1.14 & 0.90 & 6.63 & 5.68 \\
\hline & $10 \mathrm{ppm}$ & 5.74 & 6.20 & 1.16 & 1.00 & 6.66 & 6.20 \\
\hline & $25 \mathrm{ppm}$ & 5.52 & 5.95 & 1.24 & 0.90 & 6.81 & 5.36 \\
\hline & $50 \mathrm{ppm}$ & 5.14 & 5.65 & 1.36 & 1.20 & 6.99 & 6.78 \\
\hline \multirow{4}{*}{ MT-4 } & $5 \mathrm{ppm}$ & 5.82 & 6.68 & 1.14 & 0.50 & 6.63 & 3.34 \\
\hline & $10 \mathrm{ppm}$ & 5.74 & 6.57 & 1.16 & 0.50 & 6.66 & 3.29 \\
\hline & $25 \mathrm{ppm}$ & 5.52 & 6.37 & 1.24 & 0.70 & 6.81 & 4.46 \\
\hline & $50 \mathrm{ppm}$ & 5.14 & 5.97 & 1.36 & 1.50 & 6.99 & 8.95 \\
\hline
\end{tabular}


Fig.1 Total chlorophyll in rice leaves under influence of

Trichoderma spp. and cadmium stress

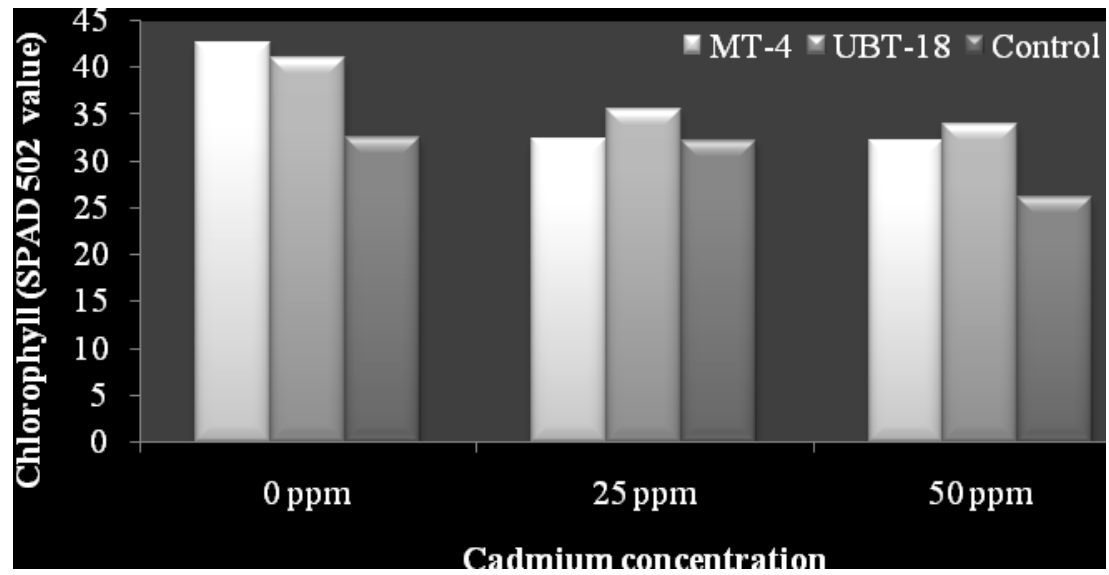

Fig.2 Variation in total protein under influence of Trichoderma spp. and cadmium stress

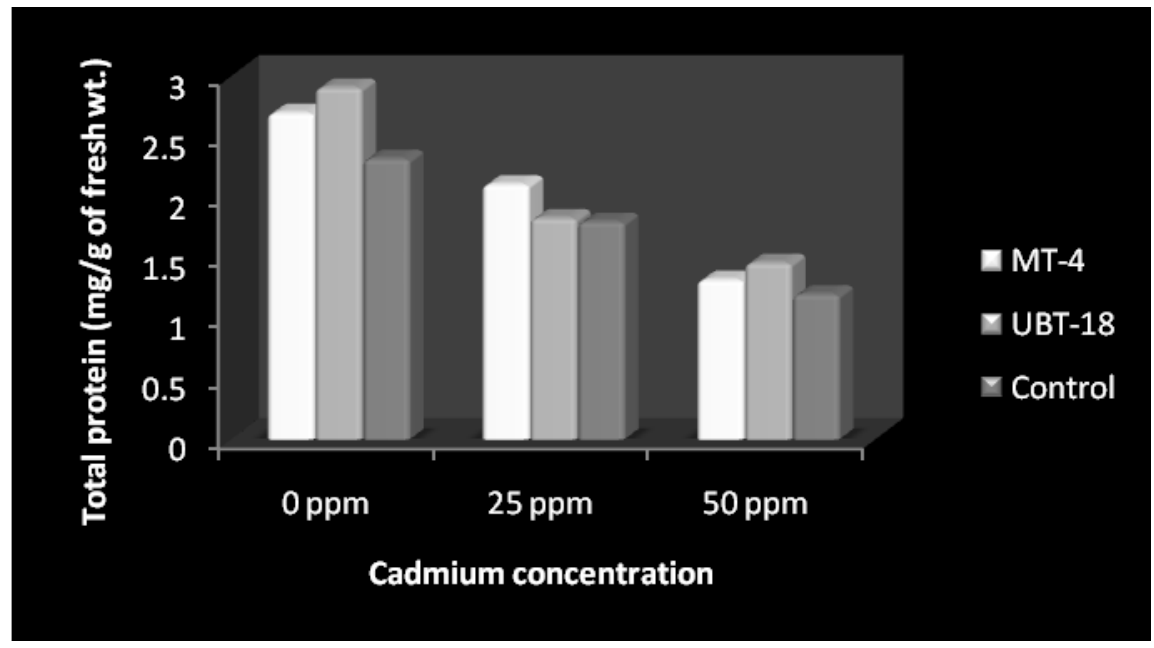

Fig.3 Peroxidase activity in rice leaves under influence of Trichoderma spp. and cadmium stress

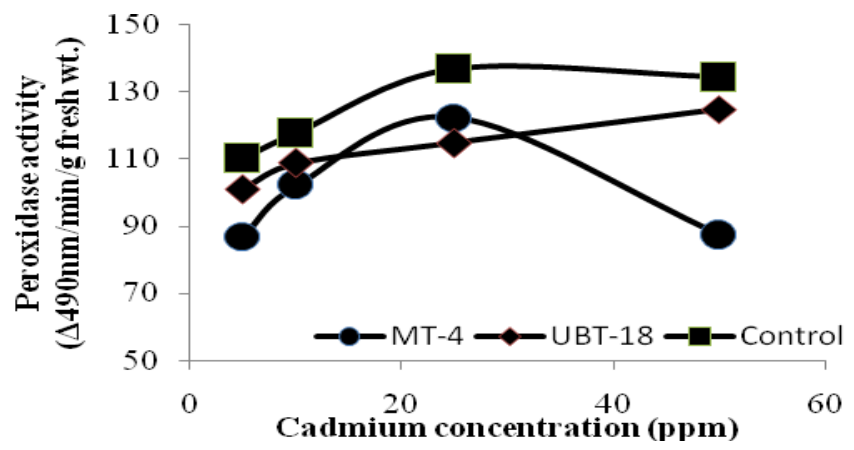


Fig. 4. Relation between plant biomass and cadmium uptake in presence of MT-4 under cadmium stress condition

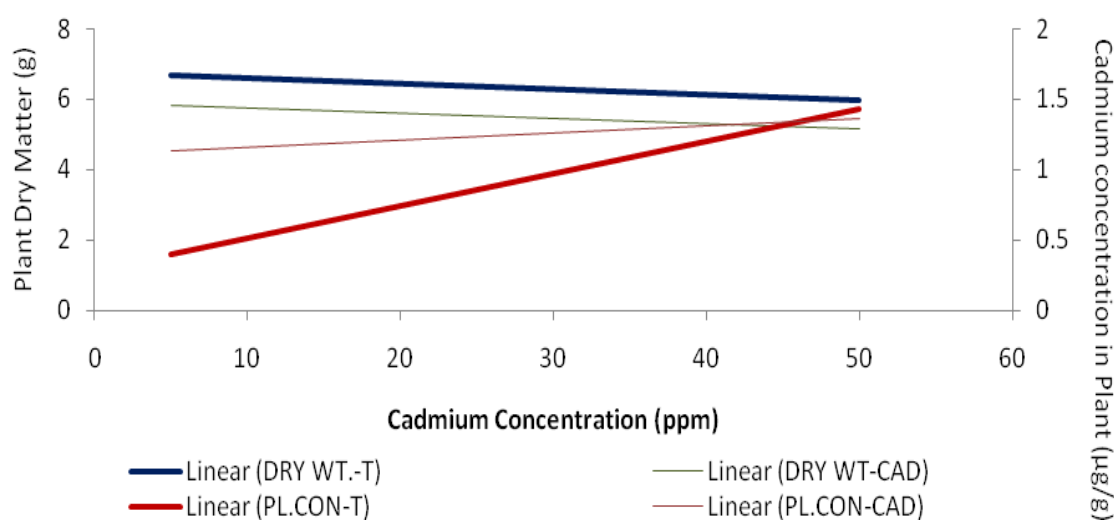

Fig. 5. Relation between plant biomass and cadmium uptake in presence of

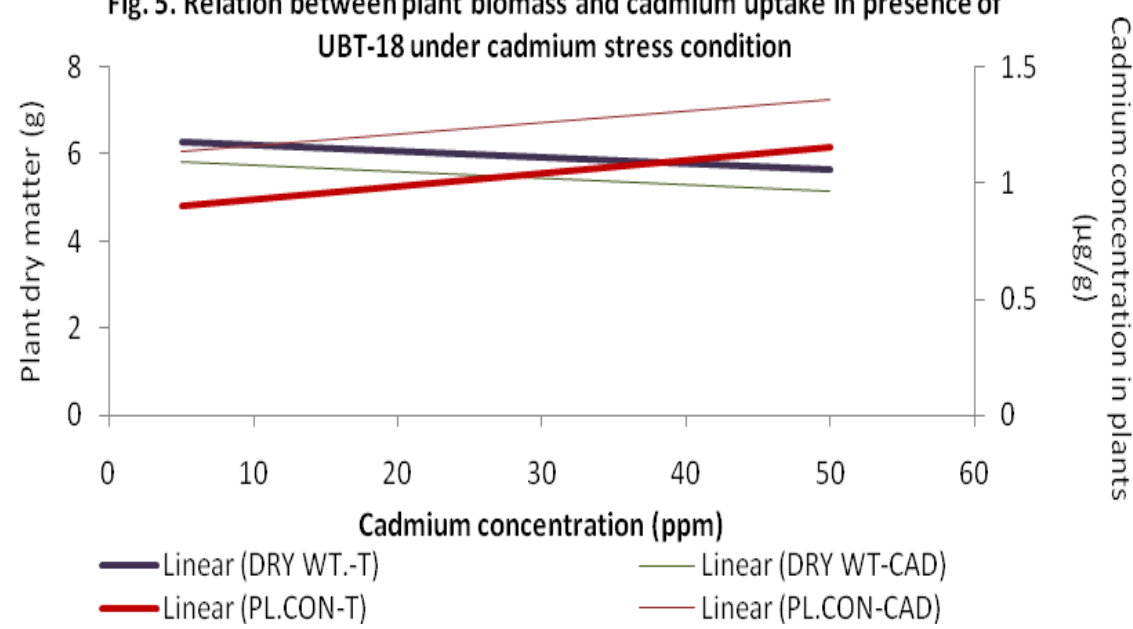

DRY WT-T= dry weight of Trichoderma treated plants; DRY WT-CAD= dry weight of Trichoderma non-treated plants only with different concentration of cadmium; PL.CON-T= cadmium concentration in Trichoderma treated plants; PL.CON-CAD= cadmium concentration of Trichoderma non-treated plants only with different concentration of cadmium.

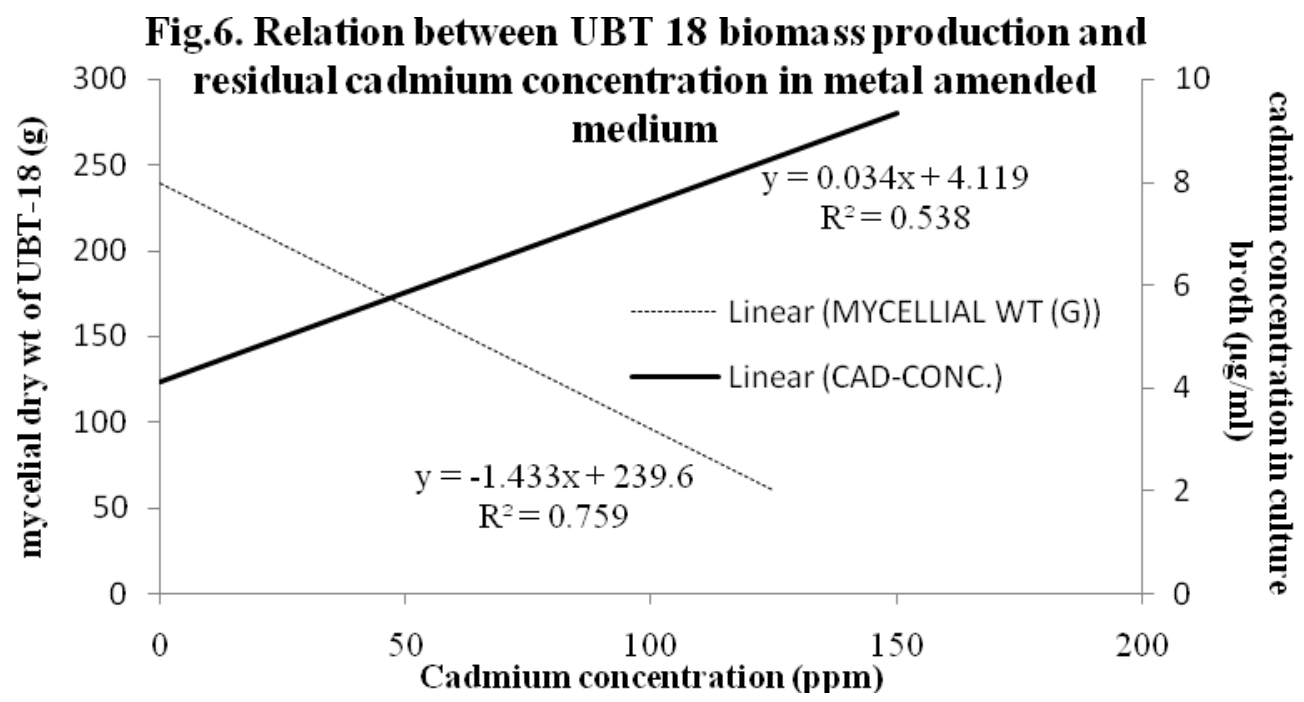


It may also results in the synthesis of phytoalexins, PR proteins and other compounds, with consequence in an increase in resistance against several plant pathogens, including fungi and bacteria (Dana et al., 2001), as well as resistance to hostile abiotic conditions (Harman et al., 2004).

During the study, it was also observed that with increase in metal contamination in Trichoderma non-treated treatment there was a significant reduction in protein content in rice leaves. Lipids and proteins are important constituents of the cell that easily damage in environmental stress condition (Prasad, 1996). Hence any change in these compounds can be considered as an important indicator of oxidative stress in plants. Variable changes in soluble protein content in different metal treatments which reflected different level of antioxidant defence (Rastgoo and Alemzadeh, 2011). It is thought that decrease in total soluble protein content under heavy metal stress may be due to protease activity (Palma et al., 2002), various structural and functional modifications by the denaturation and fragmentation of proteins (John et al., 2009), DNA-protein cross links (Atesi et al., 2004), interaction with thiol residues of proteins and replacement with heavy metals in metalloproteins (Pal et al., 2006). In Trichoderma treated plants significant increase in protein content was noted since Trichoderma has great role in induction of protein content in plants as a general phenomenon of plant growth promotion. Proteins content of shoots and roots of maize plants treated with $T$. harzianum T22 were increased (Alkadious and Abbas, 2012) attributed to ability of Trichoderma spp. to increase uptake of nitrates and other ions (Harman, 2000). Trichoderma spp. increase biological nitrogen fixation in soil and nitrogen uptake by plant (Dordas and Sioulas, 2008). T. harzianum could produce nitrogen oxide (NO) which is that coding for enzyme involved in L-arginine which is important precursor for protein biosynthesis (Gong et al., 2007). T. harzianum inoculums in soybean grown gave higher percentage of crude protein (Egberongbe et al., 2010). In addition, numerous proteins induced in response to Trichoderma were involved in stress and defense responses (Michal and Harman, 2008). The increase in total soluble protein content under heavy metal stress may be related to induction in the synthesis of stress proteins such as enzymes involved in Krebs cycle, glutathione and phytochelatin biosynthesis and some heat shock proteins (Verma and Dubey, 2003; Mishra et al., 2006).

A common feature of environmental stress is their ability for production of toxic oxygen derivatives (Arora et al., 2002). Reactive oxygen species (ROS) are continuously produced at low level during normal metabolic processes. But in biological systems, increasing the synthesis of ROS is one of the initial responses to different stress factors (Singh and Sinha, 2005). ROS induce damage to the biomolecules through peroxidation of membrane lipids, alteration of protein functions, DNA mutation, and damage to chlorophyll and disruption of some of the metabolic pathways (Semane et al., 2010). Therefore, the tolerance of plants to stress conditions depends on their ability to make balance between the production of toxic oxygen derivatives and capacity of antioxidative defense systems. which include antioxidant enzymes such as superoxide dismutase (SOD), peroxidase (POX), catalase (CAT), glutathione reductase (GR), monodehydroascorbate reductase (MDHAR) and dehydroascorbate reductase (DHAR) and low-molecular weight quenchers (cycteine, ascorbic acid, thiols, proline (Singh and Sinha, 2005), atocopherol, glutation, carotenoids, phenolic and nitrogen compounds (Michalak, 2006). In the present 
investigation, peroxidase activity was also found to be increased in Trichoderma non treated plants with increasing concentration of cadmium up to $25 \mathrm{ppm}$ followed by gradual decline. Peroxidase activity in Trichoderma treated plants was always lower compared to non-treated plants and MT-4. There are considerable evidences that activation of peoxidase activity plays a major function in biological control of pathogens and plant health management by Trichoderma spp. (Cherif et al., 2007). Diversity in peroxidase activity under heavy metal stress depends on number of biotic and abiotic factors (Tamas et al., 2008). Rastgoo and Alemzadeh (2011) observed that peroxidase activity increased with low level of metals like cobalt, lead, silver at $50 \mu \mathrm{m}$ concentration but enzyme activity decreased under severe stress due to blocking of essential functional groups, replacement of essential metals with heavy metals, changes in structure or the integrity of proteins and the interruption of signal transduction pathways of antioxidant enzymes because of poisonous active oxygen species derivatives (Schutzendube and Polle, 2002). The enhanced redox state of Trichoderma colonized plants could be explained by their higher activity of ascorbate and glutathionerecycling enzymes, higher activity of superoxide dismutase, catalase, and ascorbate peroxidase, in both root and shoot throughout crop growth. Similar enzymes were induced in uncolonized plants in response to stress but to a lower extent when compared with colonized plants. This orchestrated enhancement in activity of reactive oxygen species (ROS)-scavenging pathways in colonized plants in response to stress supports the hypothesis that enhanced resistance of colonized plants to stress is at least partly due to higher capacity to scavenge ROS and recycle oxidized ascorbate and glutathione, a mechanism that is expected to enhance tolerance to abiotic and biotic stresses (Mastouri et al., 2010).
It was observed that the plant biomass was decreased with increasing concentration of heavy metal. These results are in accord with those observed in other agricultural crops inoculated with specific strains of Trichoderma spp. by Harman et al., (2004). According to Hoyos-Carvajal et al., (2009b) the increment in biomass related to production of plant growth hormones or analogues is another mechanism by which strains of Trichoderma spp. can enhance plant growth. Various species of fungi have been reported to produce auxins, which are key hormones effecting plant growth and development that can be produced by fungi in symbiotic interactions with plants (Gravel et al., 2007). Cadmium as non-essential element was detected in Trichoderma treated and nontreated rice plants. Correlation between cadmium contamination in soil, plant biomass and cadmium uptake in rice plants suggested that plant biomass is negatively correlated with metal contamination with simultaneous increase in cadmium uptake by rice plants. Trichoderma aided in induction of defence response in plants which helped in production of more biomass and thereby reducing the cadmium uptake in plants. Negative correlation between higher biomass production by Trichoderma isolate (UBT-18) and lower residual cadmium concentration in metal amended growth medium (Fig. 6) supported the above findings in the way that cadmium was removed by the Trichoderma isolate and henceforth it remained available in lower quantity for uptake by the rice plant.

\section{References}

Akladious, S.A. and Abbas, S.M. 2012. Application of Trichoderma harziunum T22 as a biofertilizer supporting maize growth. Afr. J. Biotechnol., 11(35): 8672-8683.

Aleem, A., Isar, J. and Malik, A. 2003. Impact of long-term application of industrial waste water on the emergence of resistance traits in Azotobacter chroococcum isolated from 
rhizosperic soil. Bioresour. Technol. 86(1): 7-13.

Alloway, B.J. 1995. Heavy Metals in Soils. 2nd Ed. Blackie Academic and Professional, An imprint of Chapman and Hall, U K.

Anand, P., Isar, J., Savan, S. and Saxena, P.K. 2006. Bioaccumulation of copper by Trichoderma viride. Bioresour. Technol., 97: 1018-1025.

Arora, A., Sairam, R.K. and Srivastava, G.C. 2002. Oxidative stress and antioxidative system in plants. Curr. Sci., 82: 1227-1238.

Asada, K. 1999. The waste water cycle in chloroplast: scavenging of active oxygen and dissipation of excess photons. Annu. Rev. Plant Physiol. Plant Mol. Biol., 50: 601-639.

Atesi, I., Suzen, H.S. Aydin, A. and Karakaya, A. 2004. The oxidative DNA base damage in tests of rats after intraperitoneal cadmium injection. Biometals, 17: 371-377.

Barcelo, J. and Poschenrieder, C. 1990. Plant water relations as affected by heavy metal stress: A review. J. Plant Nut., 13: 1-37.

Benavides, M.P., Gallego, S.M. and Tomaro, M.L. 2005. Cadmium toxicity in plants. Braz. J. Plant Physiol., 17: 21-34.

Cataldo, C.D., Garland, T.R. and Wildurg, R.E. 1983. Cadmium uptake, kinetics in intact soyabean plants. Plant Physiol., 73: 844-848.

Chérif, M., Arfaoui, A. and Rhaiem, A. 2007. Phenolic compounds and their role in biocontrol and resistance of chickpea to fungal pathogenic attacks. Tunisian J. Plant Prot., 2: 7-21.

Dana, M.M., Limón, M.C., Mejías, R., Mach, R.L., Benítez, T., Pintor-Toro, J.A. and Kubicek, C.P. 2001. Regulation of chitinase 33 (chit33) gene expression in Trichoderma harzianum. Curr. Genet., 38: 335-342.

Dordas, C. and Sioulas, C. 2008. Safflower yield, chlorophyll content, photosynthesis, and water use efficiency response to nitrogen fertilization under rainfed conditions. Ind. Crops Prod., 27: 75-85.

Egberongbe, H.O., Akintokun, A.K., Babalola, O.O. and Bankole, M.O. 2010. The effect of Glomus mosseae and Trichoderma harzianum on proximate analysis of soybean (Glycine $\max$ (L.) Merrill.) Seed grown in sterilized and unsterilized soil. J. Agric. Extension Rural Dev., 2(4): 54-58.
Ezzi, M.1. and Lynch, J.M. 2005. Biodegradation of cyanide by Trichoderma spp. and Fusarium spp. Enzyme Microb. Technol., 36:8 49-854.

Foyer, C.H., Lopez-Delgado, H., Dat, J.F. and Scott, I.M. 1997. Hydrogen peroxide and glutathione-associated mechanism of acclamatory stress tolerance and signaling. Physiol. Plant, 100: 241-254.

Ghosroy, S. and Nadakavukaren, M. 1990. Influence of cadmium on ultrastructure of developing chloroplasts in soybean and corn. Environ. Exp. Bot., 30: 187-192.

Gong, X., Fu, Y., Jiang, D., Li, G., Yi, X. and Peng, Y. 2007. L-Arginine is essential for conidiation in the filamentous fungus Coniothyrium minitans. Fungal Gen. Biol., 44: 1368-1379.

Gravel, V., Antoun, H. and Tweddell, R.J. 2007. Growth stimulation and fruit yield improvement of greenhouse tomato plants by inoculation with Pseudomonas putida or Trichoderma atroviride: possible role of indole acetic acid (IAA), Soil Biol. Biochem., 39: 1968-1977.

Gupta, R., Ahuja, P., Khan, S., Saxena, R.K. and Mohapatra, H., 2000. Microbial biosorbents: meeting challenges of heavy metal pollution in aqueous solutions. Curr. Sci., 78(8): 976983.

Harman, G.E. 2000. Myth and dogmas of biocontrol changes in perceptions derived from research on Trichoderma harzianum T22. Plant Dis., 84: 377-393.

Harman, G.E. 2006. Overview of mechanisms and uses of Trichoderma spp. Phytopathol., 96: 190-194.

Harman, G.E., Howell, C.R., Viterbo, A., Chet, I. and Lorito, M. 2004. Trichoderma speciesopportunistic, avirulent plant symbionts. Nat. Rev., 2: 43-56.

Hoyos-Carvajal, L., Orduz, S. and Bissett, J. 2009. Growth stimulation in bean (Phaseolus vulgaris L.) by Trichoderma. Biol Cont., 51: 409-416.

Jaworska, M. and Dluzniewska, J. 2007. The effect of manganese ions on development and antagonism of Trichoderma isolates. Pollish J. Environ. Stud., 16(4): 549-553.

Jhon, P., Ahmad, P., Gadgil, K. and Sharma, S. 2009. Heavy metal toxicity: Effect on plant 
growth, biochemical parameters and metal accumulation by Brassica juncea L. Int. J. Plant Prod. 3: 65-76.

Kredics, L., Antal, Z., Doczi, I. and Manczinger, L. 2001a. Effect of heavy metal on growth and extracellular enzyme activity of mycoparasitic Trichoderma strains. Bull. Environ. Contamin. Toxicol., 66: 249-354.

Kredics, L., Antal, Z., Manczinger, L. and Nagy, E. 2001b. Beading of mycoparasitic Trichoderma strains for heavy metal resistance. Lett. Appl. Microbiol., 33: 112116.

Kupper, H., Kupper, F. and Spiller, M. 1998. In situ detection of heavy metal substitution chlorophyll in water plants. Photosyn. Res., 58: 123-133.

Larsson, E.H., Bordman, J.F. and Asp, H. 1998. Influence of UV-B radiation and $\mathrm{Cd}$ on chlorophyll fluorescence, growth and nutrient content in Brassica napus. J. Exp. Bot., 49: 1031-1039.

Liu, M., Liu, X, Li, M., Fang, M. and Chi, W. 2010. Neural-network model for estimating leaf chlorophyll concentration in rice under stress from heavy metals using four spectral indices. Biosystemic Eng., 106: 223-233.

Lopez Errasquin, E. And Vazquez, C. 2003. Tolerance and uptake of heavy metals by Trichoderma atroviride isolated from sludge. Chemosphere, 50(1): 137-143.

Lowry, O.H., Rosebrough, N.J., Farr, A.L. and Randall, R.J. 1951. Protein measurements with folin phenol reagent. J. Biol. Chem., 193: 265-275.

Mastouri, F., Bjorkman, T. and Harman, G. E. 2010. Seed treatment with Trichoderma harzianum alleviates biotic, abiotic, and physiological stresses in germinating seeds and seedlings. Phytopathol., 100: 12131221.

Michal, S. and Harman G.E. 2008. The Molecular Basis of Shoot Responses of Maize Seedlings to Trichoderma harzianum T22 Inoculation of the Root. Plant Physiol., 147: 2147-2163.

Mishra, S., Srivastava, S., Tripathi, R.D., Kumar, R., Seth, C.S. and Gupta, D.K. 2006. Lead detoxification by coontail (Ceratophyllum demersum L.) involves induction of phytochelatins and antioxidant system in response to this accumulation. Chemosphere, 65: 1027-1039.

Padmaja, K., Prasad, D.D.K. and Prasad, A.R.K. 1990. Inhibition of chlorophyll synthesis in Phaseolus vulgaris L. seedlings by cadmium acetate. Photosynthetica, 24: 399-405.

Pal, M., Horvath, E., Janda, T., Paldi, E. And Szalai, G. 2006. Physiological changes and defense mechanisms induced by cadmium stress in maize. Plant Nutr. Soil Sci., 169: 239-246.

Palma, J.M., Sandalio, L.M., Corpas, F.J., Romero-Puertas, M.C., McCarthy, I. and Del Rio, L.A. 2002. Plant proteases, protein degradation and oxidative stress: role of peroxisomes. Plant Physiol. Biochem., 40: 521-530.

Parveen, R., faizan, S., Tiyagi, S.A. and Kausar, S. 2011. Performance of Cd stress condition on growth and productivity parameters of Trigonella foenum-graceum Linn. World. J. Agric. Sci., 7(5): 607-612.

Poscherieder, C., Gunse, G. and Barcelo, J. 1989. Influence of cadmium on waste water relations stomatal resistance and abscisic acid content in expanding bean leaves. Plant Physiol., 90: 1365-1371.

Prasad, M.N.V. and Strzalka, K. 1999. Impact of heavy metals on photosynthesis. In: Prasad, M.N.V. and Hagemeyer, J. (Eds) Trees: heavy metal stress in plants: from molecules to ecosystems. p. 117-138. Springer, Berlin.

Prasad, T.K. 1996. Mechanism of chillinginduced oxidative stress injury and tolerance in developing maize seedlings: changes in antioxidant system, oxidation of proteins and lipids, and protease activities. Plant J., 10: 1017-1026.

Rastgoo, L. and Alemzadeh 2011. Biochemical response of Gouan (Aeluropus littoralis) to heavy metal stress. Australian J. Crop Sci., 5(4): 375-383.

Rauser, W.E. and Meuwly, P. 1995. Retention of cadmium in roots of maize seedlings. Role of complexation by phytochelatins and related thiol peptides. Plant Physiol., 109: 195-202.

Sadavisam, S. and Manickam, A. 1996. Biochemical Methods 2nd Edition. New Age International Publishers, New Delhi, India, $256 \mathrm{p}$. 
Salt, D., Price, R., Pickering, I. and Raskin, I. 1995. Mechanisms of cadmium mobility and accumulation in Indian mustard. Plant Physiol., 109: 1427-1433.

Schutzendubel, A. and Polle, A. 2002. Plant responses to abiotic stresses: heavy metal induced oxidative stress and protection by mycorrhization. Exp. Bot., 53: 1351-1365.

Semane, B., Dupae, J., Cuypers, A., Noben, J.P., Tuomainen, M., Tervahauta, A., Karenlampi, S., Belleghem, F.V., Smeets, K. and Vangronsveld, J. 2010. Leaf proteome responses of Arabidiopsis thaliana exposed to mild cadmium stress. Plant Physiol., 167: 247-254.

Sidlecka, A. and Baszynsky, T. 1993. Inhibition of electron flow around photosystem I in chloroplasts of cadmium treated maize plants is due to cadmium induced iron deficiency. Physiol. Plant, 87: 199-202.

Singh, S. and Sinha, S. 2005. Accumulation of metals and its effect in Brassica juncea (L.) Czern (cv. Rohini) grown on various amendments of tannery waste. Ecotoxicol. Environ. Saf., 62: 118-127.
Tamas, L., Dudikova, J., Durcekova, K., Huttova, J., Mistrik, I. and Zelinova, V. 2008. The impact of heavy metals on the activity of some enzymes along the barley root. Environ. Exp. Bot., 62: 86-91.

Tandon, H.L.S. 2005. Methods of Analysis of Soils, Plants, Waters, Fertilisers and Organic Manures. Fertilisers Development and Consultation Organisation, New Delhi. India. Pp.86-87.

Thapar, R., Srivastava, A.K., Bhargava, P., Mishra, Y. and Rai, L.C. 2008. Impact of different abiotic stress on growth, photosynthetic electron transport chain, nutrient uptake and enzyme activities of $\mathrm{Cu}-$ acclimated Anabaena doliolum. J. Plant Physiol., 165: 306-316.

Ting, A.S.Y. and Choong, C.C. 2009. Bioaccumulation and biosorption efficacy of Trichoderma isolates SP2F1 in removing Copper (Cu II) from aqueous solutions. World J. Microbiol. Biotechnol., 25: 14311437.

Van Assche, F. and Clijsters, H. 1990. Effect of metals on enzyme activity in plants. Plant Cell Environ., 13: 195-206.

\section{How to cite this article:}

Nongmaithem N., A. Roy and Bhattacharya, P.M. 2017. Potential of Trichoderma spp. on Growth Promotion and Mitigating Cadmium Uptake in Rice Plant under the Metal Stress Ecosystem. Int.J.Curr.Microbiol.App.Sci. 6(6): 992-1010. doi: https://doi.org/10.20546/ijcmas.2017.606.116 